\title{
Structural Studies on Linear Polyurethanes. II. Crystal and Molecular Structures of Aliphatic Polyurethanes from Trimethylene Diisocyanate, and Tetra- and Hexa-Methylene Glycols
}

\author{
Yasushi SAITO, Kazuaki HARA, and Shigetake KINOSHITA \\ Department of Fibers and Polymers, Faculty of Technology, \\ Gunma University, Tenjin-cho, Kiryu 371, Japan.
}

(Received April 16, 1981)

\begin{abstract}
The crystal structures of polyurethanes with the formula $-\left(\mathrm{O}-\left(\mathrm{CH}_{2}\right)_{m}-\mathrm{O}-\mathrm{C}-\mathrm{N}-\right.$ $\left.\left(\mathrm{CH}_{2}\right)_{3}-\mathrm{N}-\mathrm{C}-\right)_{p}-(m=4,6)$ have been determined by $\mathrm{X}$-ray diffraction analysis. Poly(tetramethylene trimethylene dicarbamate) (4,3-polyurethane) crystallizes in the triclinic space group $\mathrm{P} \overline{1}-\mathrm{C}_{\mathrm{i}}^{1}$ with $a=5.06 \AA, b=5.04 \AA, c\left(\right.$ fiber axis) $=30.10 \AA, \alpha=112^{\circ}, \beta=113^{\circ}$, and $\gamma=110^{\circ}$. Poly(hexamethylene trimethylene dicarbamate) (6,3-polyurethane) crystallizes in the triclinic space group $\mathrm{P} \overline{1}-\mathrm{C}_{\mathrm{i}}^{1}$, with $a=5.04 \AA, b=5.04 \AA, c=34.65 \AA . \alpha=111^{\circ}, \beta=111^{\circ}$, and $\gamma=111^{\circ}$. By conformational analysis, we attempted to find structure models that would satisfy the condition of full intermolecular hydrogen bonding. These models were then refined by three dimendional Fourier synthesis to the $R$ values of 0.225 for 4,3- and 0.207 for 6,3-polyurethane. The molecules of both polymers are linked two dimensionally by $\mathrm{C}=\mathrm{O} \cdots \mathrm{H}-\mathrm{N}$ hydrogen bonds. These polymers are the same in structure except for their fiber periods which differ in the length of two methylene groups of the glycols. The hydrogen bonding patterns of these polyurethanes differ from those of other polyurethanes.
\end{abstract}

KEY WORDS Linear Polyurethane / X-Ray Diffraction / Poly(tetramethylene trimethylene dicarbamate) / Poly(hexamethylene trimethylene dicarbamate) / Conformational Analysis / Hydrogen Bonding / Fourier Synthesis /

Linear polyurethanes consisting of aliphatic diisocyanates and glycols are expressed by the general formula

$$
-\left(-\mathrm{O}-\left(\mathrm{CH}_{2}\right)_{m}-\underset{\mathrm{O}}{\mathrm{O}} \stackrel{\mathrm{H}}{\mathrm{H}}-\left(\mathrm{CH}_{2}\right)_{\mathrm{n}}-\stackrel{\mathrm{H}}{\mathrm{N}}-\right)_{\mathrm{O}}^{-},
$$

where $m$ and $n$ represent the number of methylene groups of glycol and diisocyanate, respectively, and are referred to as $m, n$-polyurethanes. The crystal and molecular structures of $m, 6$-polyurethanes were investigated in the previous paper. ${ }^{1}$ Two types of molecular structures were reported as planar zigzag and twisted conformations, depending on whether $m$ is even or odd.

More recently, the crystal structures of two cyclic urethane oligomers, cyclobisurethane and cyclotetraurethane, which are the dimer and tetramer of 4,6-polyurethane, have been determined by single crystal X-ray diffraction analysis. ${ }^{2}$ The bond lengths and angles of these compounds are considered to be appliceable to $m, n$-polyurethanes.

In this paper, the crystal and molecular structures of 4,3- and 6,3-polyurethanes were investigated mainly by X-ray diffraction, and compared with previous work on other polyurethanes. The samples used were prepared from trimethylene diisocyanate $(n=3)$ and two linear glycols, which are poly(tetramethylene trimethylene dicarbamate) for $m=4$, and poly(hexamethylene trimethylene dicarbamate) for $m=6$.

\section{EXPERIMENTAL}

\section{Materials}

The polymers were prepared by direct reaction of the glycols and trimethylene diisocyanate. ${ }^{3}$ 
Trimethylene diisocyanate was prepared by the Curtius inversion of trimethylene diazide. ${ }^{4}$ After placing a slight excess (to avoid chain branching and crosslinking) of a glycol in a reaction vessel under dry nitrogen gas, trimethylene diisocyanate was added over a period of $1 / 2$ to $1 \mathrm{~h}$, while the temperature was raised gradually above the melting point of the polymer. Each polymer was purified by dissolving it in a very small amount of $N, N^{\prime}$ dimethylformamide and by reprecipiating with methanol. The melting points were $162^{\circ} \mathrm{C}$ for $4,3-$ and $142^{\circ} \mathrm{C}$ for 6,3-polyurethanes. The samples were spun from melt, stretched to $500-1000 \%$ at room temperature, and annealed at $115-120^{\circ} \mathrm{C}$ for several hours in silicone oil.

\section{$X$-Ray Diffraction Methods}

The X-ray diffraction patterns were recorded on photofilms using $\mathrm{CuK} \alpha$ radiation (from a Rigaku Denki, Rotaflex X-ray generator) filtered through a $\mathrm{Ni}$ foil or monochromatized by a LiF single crystal. For obtaining the X-ray fiber photographs monofilaments about $0.5 \mathrm{~mm}$ in diameter were used. Standard fiber patterns were taken with the incident beam perpendicular to the fiber axis. Inclination fiber photographs were taken for a precise estimation of the fiber periods. For estimating intensity, the multiple film method was applied to the cylindrical photographs, and the diffraction spots were measured by visual comparison with a standard intensity scale. The usual corrections were made for spot intensities.

\section{Density Measurements}

Density measurements were made by the floatation method, with a carbon tetrachloride-ethanol mixture as the floatation medium. The density of the floatation medium was determined by a LipkinDavison type pycnometer.

\section{Infrared Spectra}

Infrared absorption spectra in the 4000 $650 \mathrm{~cm}^{-1}$ region were taken on a Japan Spectroscopic Co. Model IRA-I spectrometer. The specimens used were prepared by annealing the polymers under the same conditions as those in $\mathrm{X}$ ray diffraction studies, and shaped to the form of a $\mathrm{KBr}$ disk.

\section{RESULTS AND DISCUSSION}

\section{Infrared Spectra and Hydrogen Bondings}

Infrared spectra of 4,3- and 6,3-polyurethane are shown in Figure 1. No appreciable difference in their absorption bands can be seen, especially in the range of $\mathrm{N}-\mathrm{H}$ stretching absorption bands (3500$3000 \mathrm{~cm}^{-1}$ ).

The basic data on the hydrogen bonding in polyurethanes were obtained by Tanaka et al. ${ }^{5}$ and by MacKnight and Yang. ${ }^{6}$ These authors found that the free $\mathrm{N}-\mathrm{H}$ stretching vibration peak appeared near $3440 \mathrm{~cm}^{-1}$ and the hydrogen-bonded one near $3300 \mathrm{~cm}^{-1}$. In this study, no (otherwise very weak) free $\mathrm{N}-\mathrm{H}$ absorption bands were observed in the spectra of both polymers. For the for-

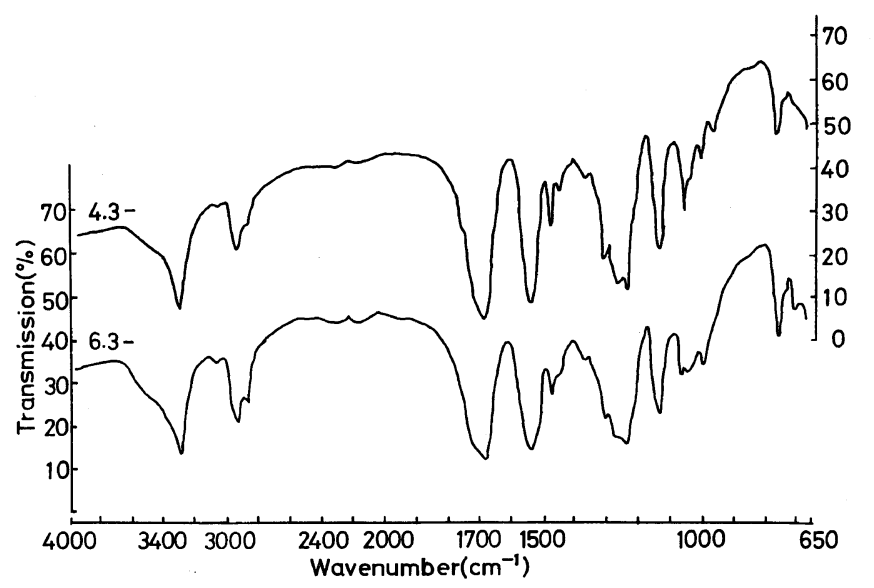

Figure 1. Infrared spectra of 4,3- and 6,3-polyurethane. 


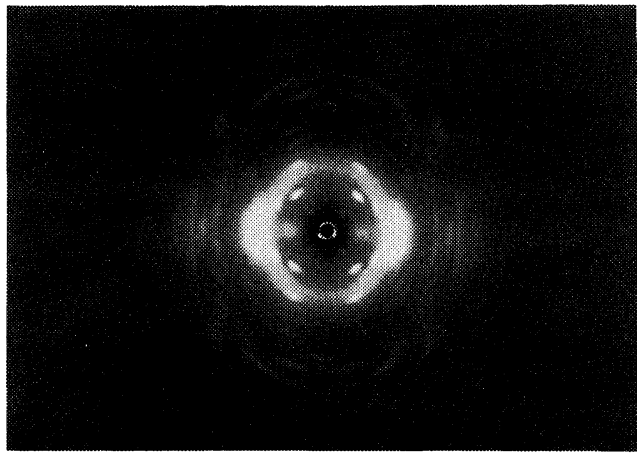

(a)

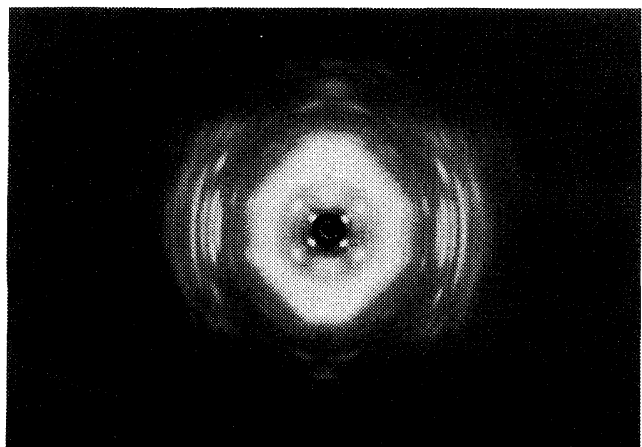

(b)

Figure 2. X-ray fiber photographs: (a) 4,3-polyurethane; (b) 6,3-polyurethane.

mation of polyurethane crystals, the $\mathrm{N}-\mathrm{H} \cdots \mathrm{O}$ hydrogen bonding between the urethane groups of adjacent chains is particularly important. ${ }^{1}$ When the molecular chains of the $m, n$-polyurethanes with even $m$ and even $n$ are in the fully stretched state, the neighbouring chains are completely bridged by hydrogen bonds. In the polymers with odd $m$ and even $n$ or those with even $m$ and odd $n$, only $50 \%$ of $\mathrm{N}-\mathrm{H} \cdots \mathrm{O}$ hydrogen bondings would be formed if they were in the fully extended conformation. Since the infrared spectra of the $m, 3$-polyurethanes show that most of the $\mathrm{N}-\mathrm{H}$ groups in the crystalline region are hydrogen bonded, as shown in Figure 1, the conformations of these polymers should be different from the stretched planar zig-zag.

\section{Unit Cells and Space Groups}

Figures $2 \mathrm{a}$ and $2 \mathrm{~b}$ give the $\mathrm{X}$-ray fiber photographs of uniaxially oriented samples of 4,3- and 6,3-polyurethane, respectively. The diffraction spots on the photographs can be indexed by the lattice
Table I. Crystal data

\begin{tabular}{|c|c|c|}
\hline & $\begin{array}{l}\text { 4,3-Poly- } \\
\text { urethane }\end{array}$ & $\begin{array}{l}\text { 6,3-Poly- } \\
\text { urethane }\end{array}$ \\
\hline Crystal system & Triclinic & Triclinic \\
\hline Space Group & $\mathrm{P} \overline{1}-\mathrm{C}_{\mathrm{i}}^{1}$ & $\mathrm{P} \overline{1}-\mathrm{C}_{\mathrm{i}}^{1}$ \\
\hline \multicolumn{3}{|l|}{ Cell parameters } \\
\hline$a / \AA ̊$ & 5.06 & 5.04 \\
\hline$b / \AA$ & 5.04 & 5.04 \\
\hline$c / \AA^{\mathrm{a}}$ & 30.10 & 34.65 \\
\hline$\alpha /^{\circ}$ & 112 & 111 \\
\hline$\beta /^{\circ}$ & 113 & 111 \\
\hline$\gamma /^{\circ}$ & 110 & 111 \\
\hline \multicolumn{3}{|l|}{ Numbers of repeating } \\
\hline units per unit cell & 2 & 2 \\
\hline \multicolumn{3}{|l|}{ Density $/ \mathrm{g} \cdot \mathrm{cm}^{-3}$} \\
\hline Observed $^{\mathrm{b}}$ & 1.26 & 1.21 \\
\hline Calculated & 1.31 & 1.25 \\
\hline Reflections observed & 57 & 70 \\
\hline
\end{tabular}

a Fiber identity period.

${ }^{b}$ Determined by the floatation method at $25^{\circ} \mathrm{C}$.

parameters of triclinic cells given in Table I. The fiber identity periods were determined by applying the tilt method $^{7}$ to the 006 spots of the respective unit cells. The maximum values of $\phi_{\max }^{\prime}$ of the aximuthal angles of these spots relative to the meridional lines in the flat plate camera were measured by tilting the fiber axis to the incident X-ray beam. The aximuthal angles $\phi$ between the reciprocal vectors of these spots and the molecular axis were calculated. From the values of the Bragg angle $2 \theta$ and the interplanar spacings $d$ corresponding to the spots, the fiber identity periods $c$ were determined more precisely, according to,

$$
\begin{aligned}
& \sin \phi=\sin \phi_{\max }^{\prime} \cdot \cos \theta \\
& c=l \cdot d / \cos \phi
\end{aligned}
$$

where $l$ is the index of the layer line for the spots, being 6 in this case.

The measured densities of our polymers are reasonable when compared with those calculated by assuming two chemical repeating units per unit cell, as shown in Table I.

The space groups of both polymers are either P1$C_{1}^{1}$ or $P \overline{1}-C_{i}^{1}$. If the molecules possess centers of symmetry in the crystal, the space group is the latter. As mentioned below, in both polymers, the molecules which satisfy the requirement of full hydrogen bonding and the fiber identity periods 


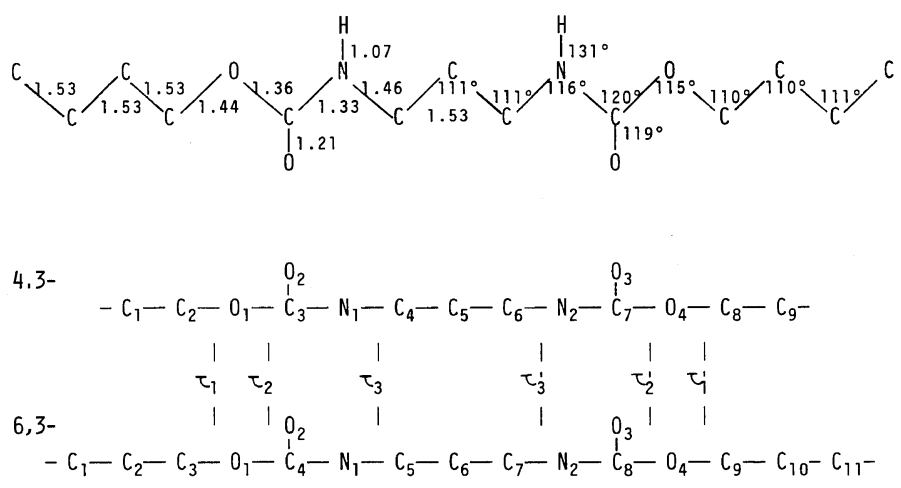

Figure 3. Bond lengths, bond angles and the numbering of atoms and internal rotation angles of 4,3- and 6,3-polyurethane. The internal rotation angles not numbered are trans $\left(\tau=180^{\circ}\right)$.

have centers of symmetry at the mid-points of the methylene groups of the glycols. Therefore, the space groups of our polymers can uniquely be assumed to be $\mathrm{P} \overline{1}-\mathrm{C}_{\mathrm{i}}^{1}$.

\section{Molecular Conformation}

The assumed bond lengths and bond angles are shown in Figure 3 and are those of cyclic urethane oligomers determined by single-crystal X-ray diffraction analysis by Beres and Alexander. ${ }^{2}$ The fiber periods for the planar zig-zag conformations of 4,3- and 6,3-polyurethanes were calculated to be $31.46 \AA$ and $36.50 \AA$, respectively, assuming two chemical repeating units per fiber period. Comparison of the measured fiber identity periods with those calculated indicates that the polymer chains in the crystal should be distorted from the planar zig-zag.

By varying the internal rotation angles and fixing the bond lengths and bond angles as above, we attempted to find molecular conformations which would satisfy the requirement of full hydrogen bonding and the fiber identity periods. The conformations leading to the calculated fiber identity periods consistent with those observed were obtained assuming the following three conditions:

(1) The atoms in the urethane group are coplanar. The methylene chains of both the glycol and the diisocyanate groups are maintained in the zigzag conformation. But the internal angles around $(\mathrm{C}-\mathrm{C}-\mathrm{O}-\mathrm{C}(=\mathrm{O}), \mathrm{C}-\mathrm{O}-\mathrm{C}(=\mathrm{O})-\mathrm{N}$, and $\mathrm{C}(=\mathrm{O})$ $\mathrm{N}-\mathrm{C}-\mathrm{C}$, denoted by $\tau_{1}, \tau_{2}$, and $\tau_{3}$, respectively and shown in Figure 3, can be varied to adjust the fiber identity period. This assumption is similiar to that

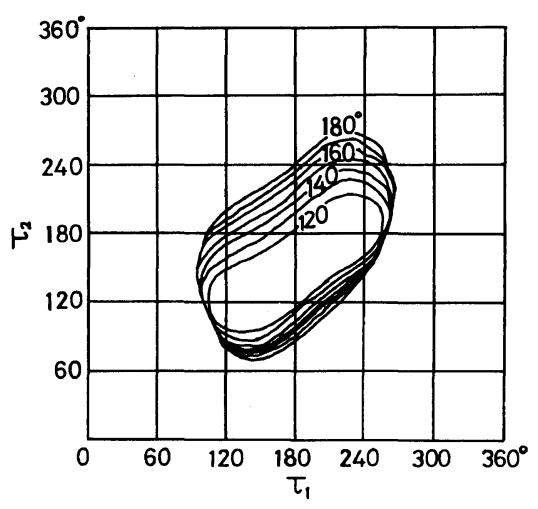

Figure 4. Several cross sections of the closed surface of a cube defined by $\tau_{1}, \tau_{2}$, and $\tau_{3}$ for possible conformations of 6,3-polyurethane with glide symmetry and fiber period of $34.65 \AA$.

used in the studies of polyesters ${ }^{8}$ and polypeptides ${ }^{9}$;

(2) In the asymmetric unit, the corresponding internal rotation angles $\tau_{1}, \tau_{2}, \tau_{3}$ have the same values and signs, that is, $\tau_{1}=\tau_{1}^{\prime}, \tau_{2}=\tau_{2}^{\prime}$, and $\tau_{3}=\tau_{3}^{\prime}$;

(3) The polymers have glide symmetry, ${ }^{10}$ i.e., the corresponding internal rotation angles of the neighbouring structural repeating units in the identity period are going opposite in sign.

On these assumptions, the acceptable values of $\tau_{1}$, $\tau_{2}$, and $\tau_{3}$ were calculated. The possible conformations are limited to the closed surface in a cube defined by the three dimensional Cartesian coordinates $\tau_{1}, \tau_{2}, \tau_{3}$, each ranging from 0 to $360^{\circ}$. In Figure 4 , cross sections of the closed surface at constant $\tau_{3}$ for 6,3-polyurethane are illustrated.

If $\tau_{3}$ is given, there are two values of $\tau_{2}$ for a given 
value of $\tau_{1}$, as can be seen from Figure 4 .

In the study of polymer structure, we usually try to calculate intra- (and/or inter-) molecular potential energy to find one or more molecular models which will minimize the potential energy and satisfy other conditions. In this study, a more conventional

Table II. Temperature factor coefficients in parentheses, coefficients of general temperature factors

\begin{tabular}{lll}
\hline & 4,3-Polyurethane & 6,3-Polyurethane \\
\hline$B_{11}$ & $0.1088\left(6.5 \AA^{2}\right)$ & $0.0876\left(5.5 \AA^{2}\right)$ \\
$B_{22}$ & $0.1088\left(6.5 \AA^{2}\right)$ & $0.0876\left(6.5 \AA^{2}\right)$ \\
$B_{33}$ & $0.0022\left(4.5 \AA^{2}\right)$ & $0.0012\left(3.5 \AA^{2}\right)$ \\
$B_{12}$ & $0.0734\left(7.0 \AA^{2}\right)$ & $0.0627\left(6.0 \AA^{2}\right)$ \\
$B_{23}$ & $0.0062\left(6.0 \AA^{2}\right)$ & $0.0028\left(5.0 \AA^{2}\right)$ \\
$B_{31}$ & $0.0062\left(6.0 \AA^{2}\right)$ & $0.0028\left(5.0 \AA^{2}\right)$ \\
\hline
\end{tabular}
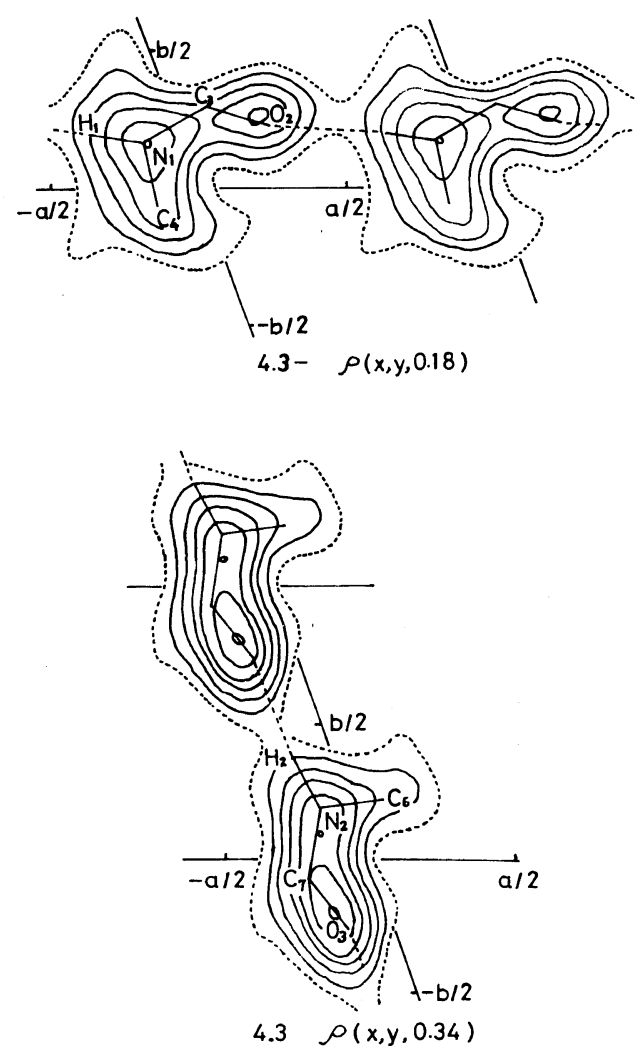

(a) method was used to find the most suitable model for polyurethanes, i.e., the molecular structure that would form full hydrogen bonding between neighbouring chains.

Hydrogen bonds are stronger than van der Waals bonds, but much weaker than covalent bonds, and play an important role in the structure and function of polypeptides, ${ }^{9,10}$ polyamides, ${ }^{12}$ polyurethanes ${ }^{1,2}$ and numerous other polymers. One important feature of hydrogen bonds is that they are highly directional. ${ }^{13}$ The strongest hydrogen bond appears when the donor, hydrogen, and acceptor atoms are colinear. If the acceptor atom deviates from the line joining the donor and the hydrogen atoms, the bond is weaker. It was assumed that our polyurethane molecules should be stabilized by the formation of $\mathrm{N}-\mathrm{H} \cdots \mathrm{O}$ bonds between the adjacent chains, the $\mathrm{N}-\mathrm{H} \cdots \mathrm{O}$ bond being linear (within about $10^{\circ}$ ), and

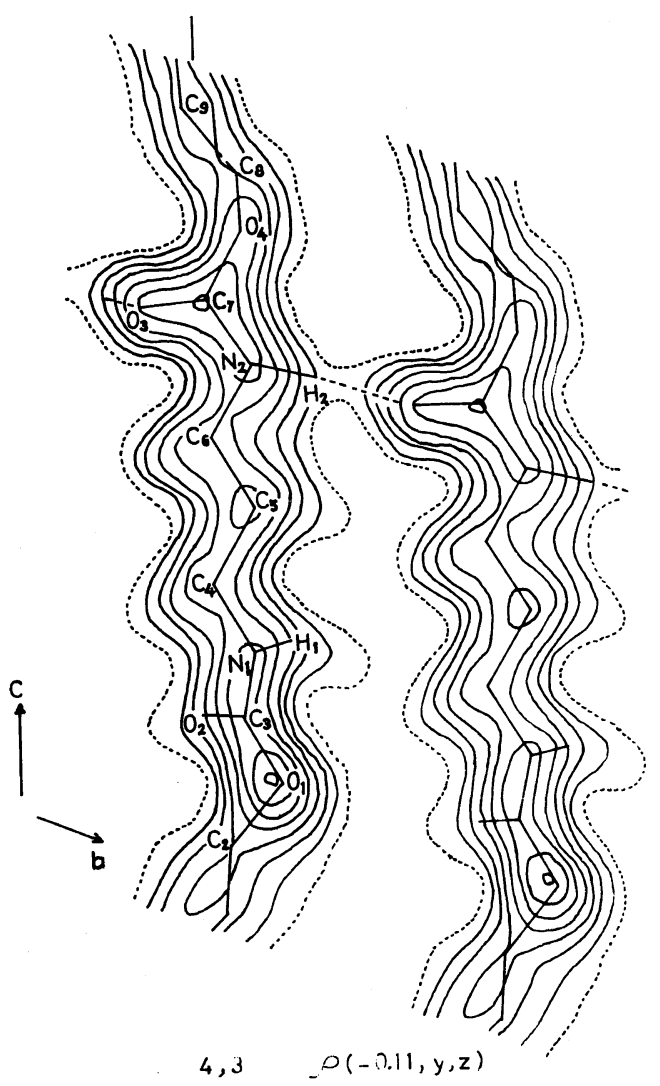

(b)

Figure 5. Sections of three-dimensional electron density distributions of 4,3-polyurethane: (a) upper at $z=0.18$; lower at $z=0.34$, and (b) at $x=-0.11$. The dotted curves indicate the level of 0.0 electron $/ \AA^{3}$ and the interval of contour is 1.0 electron $/ \AA^{3}$. 
the nitrogen-oxygen distance being equal to $2.80 \AA$. On the closed surface shown in Figure 4, we must find a conformation leading to full hydrogen bonding between the adjacent chains. Since the unit cell contains one chain consisting of two repeating units, all the molecules should have the same conformation. Thus, we set the molecules at the lattice points with the axes in the direction of the $c$-axis and their centers of symmetry coincident with those of the crystal lattice, and allowed them to rotate by the same angle around the molecular axes. By rotating the molecules with a given set of $\tau_{1}, \tau_{2}, \tau_{3}$ around their molecular axes, we checked whether the full hydrogen bonding could be formed between them. When full hydrogen bonding could not be formed, we chose another set of $\tau_{1}, \tau_{2}, \tau_{3}$ and checked the full formation of hydrogen bonding.

The model obtained in this way was such that the hydrogen bonds are half parallel to the $a$-axis and
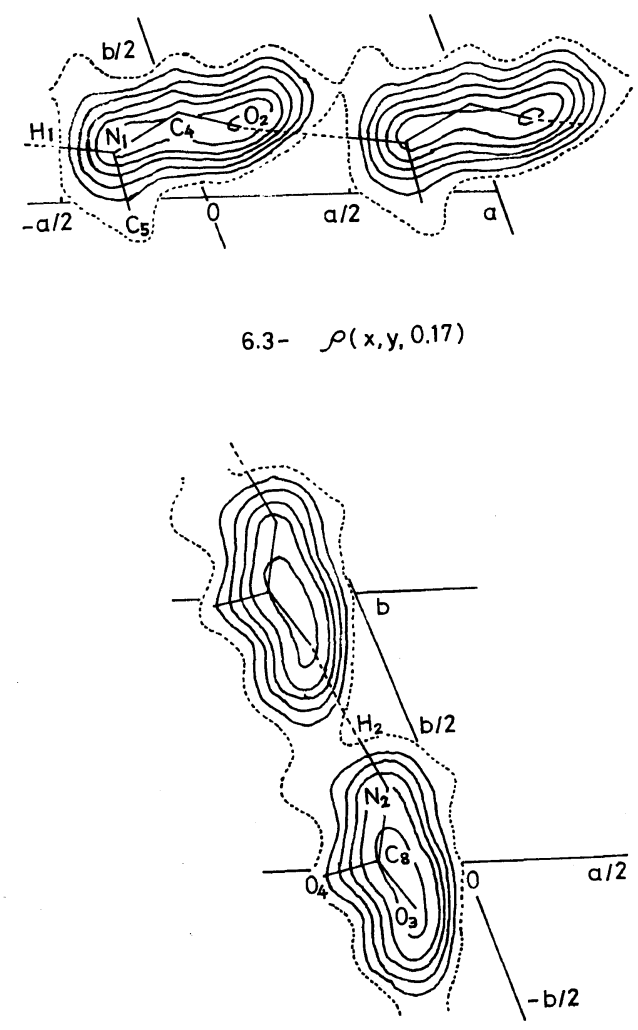

$6.3-\quad(x, y, 0.33)$

(a) half to the $b$-axis. For 6,3-polyurethane, the bond lengths of $\mathrm{N}-\mathrm{H} \cdots \mathrm{O}$ were $2.88 \AA$ and the angles $\mathrm{N}-\mathrm{H} \cdots \mathrm{O}$ were $168^{\circ}$ for both directions. The values of internal rotation angles were $\tau_{1}=-110^{\circ}, \tau_{2}=$ $-111^{\circ}$, and $\tau_{3}=150^{\circ}$. The corresponding values for 4,3-polyurethane were almost the same as those for 6,3-polyurethane when determined by the same method.

\section{Crystal Structure}

The above procedure of conformational analysis led to a preliminary structural model for each of 4,3- and 6,3-polyurethanes. The atomic coordinates derived from the models were used to calculate the structure factors, assuming the isotropic temperature factor $B$ to be $7.0 \AA^{2}$ and $4.0 \AA^{2}$ for 4,3 - and 6,3-polyurethane, respectively. The structure factors of the observed overlapped spots were partitioned in proportion to the calculated ones. At this stage,

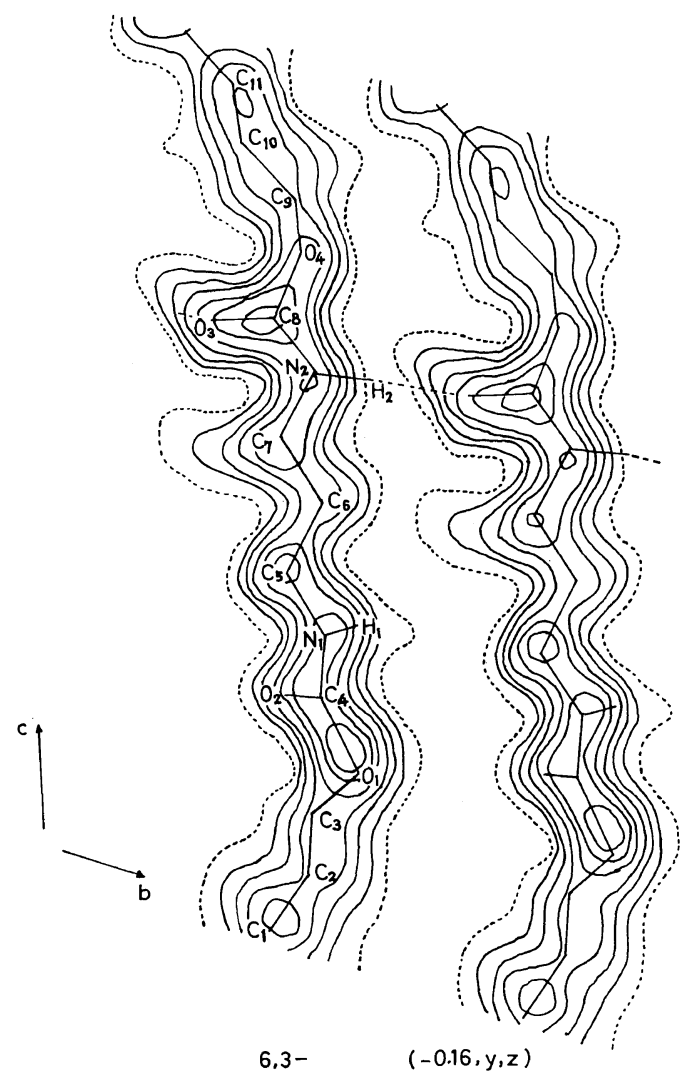

(b)

Figure 6. Sections of three-dimensional electron density distributions of 6,3-polyurethane: (a) upper at $z=0.17$; lower at $z=0.33$, and (b) at $x=-0.16$. 
the discrepancy factors $R=\Sigma|| F_{0}|-| F_{\mathrm{c}}|| / \Sigma\left|F_{0}\right|$ for all the observed reflections were $27.9 \%$ for $4,3-$ polyurethane and $26.1 \%$ for 6,3-polyurethane.

For determining a more precise crystal structure, three-dimensional Fourier synthesis was made. Since the hydrogen bond has a smaller bond energy and a weaker rigidity (i.e., resistance to compression or extension) than covalent bonds, greater thermal displacement of the atoms occurs in the direction connected by hydrogen bonds than by covalent bonds. Thus, the assumption that the temperature factors are isotropic is not correct and the values of $B$ should be different for different directions. The discrepancy factors were much improved by introducing the anisotropic temperature factors as,

$$
\begin{aligned}
\exp \{ & -\left(h^{2} B_{11}+k^{2} B_{22}+l^{2} B_{33}\right. \\
& \left.\left.+2 h k B_{12}+2 k l B_{23}+2 l h B_{31}\right)\right\}
\end{aligned}
$$

with the coefficients given in Table II.

The electron density patterns of our polymers are illustrated in Figures 5 and 6. Figures $5 \mathrm{a}$ and $6 \mathrm{a}$ show the sections at $(x, y, 0.18)$ and $(x, y, 0.34)$ for 4,3-polyurethane, where the electron densities of the atoms forming the hydrogen bonds are parallel to the $a c$ and $b c$-planes. As shown in Figures $5 \mathrm{~b}$ and $6 \mathrm{~b}$, the electron density sections parallel to the $b c$ plane indicate the peaks which are consistent with the assumed atomic positions and the electron density distributions corresponding to the hydrogen bonds. The atomic parameters are the same as those shown in Figure 3, but the bond angle $\mathrm{C}-\mathrm{N}-\mathrm{C}(=\mathrm{O})$ changes from $116^{\circ}$ to $121^{\circ}$. The internal rotation angles $\tau_{1}, \tau_{2}$, and $\tau_{3}$ are $-110^{\circ},-111^{\circ}$, and $154^{\circ}$, respectively, for 4,3 -polyurethane, and $-111^{\circ}$, $-112^{\circ}$, and $153^{\circ}$ for 6,3 -polyurethane. The atomic coordinates of these structures are listed in Table III, and the resultant discrepancy factors are $22.5 \%$ and $20.7 \%$ for $4,3-$ and 6,3-polyurethane, respectively. The calculated and observed values of the structure factor are listed in Table IV.

In these structures, the lengths of $\mathrm{N}-\mathrm{H} \cdots \mathrm{O}$ are $2.92 \AA$ and the angles of $\mathrm{N}-\mathrm{H} \cdots \mathrm{O}$ are $178^{\circ}$ for both $a$ - and $b$-directed hydrogen bonds. The crystal structures are shown in Figures 7 and 8. In Figures $7 \mathrm{a}, \mathrm{b}$ and $8 \mathrm{a}, \mathrm{b}$, the projections on the $(1 \overline{2} 0)$ and (210) planes, which are perpendicular to the hydrogen bond directions, show that every two hydrogen bonds are alternatively parallel to the $b c$ and the $a c$ plane. Figures $7 \mathrm{c}$ and $8 \mathrm{c}$ show the projections
Table III. Fractional atomic coordinates (a) 4,3-Polyurethane

\begin{tabular}{lrrl}
\hline Atom & \multicolumn{1}{c}{$x$} & \multicolumn{1}{c}{$y$} & $z$ \\
\hline $\mathrm{C}_{1}$ & 0.080 & 0.134 & 0.032 \\
$\mathrm{C}_{2}$ & -0.167 & 0.017 & 0.049 \\
$\mathrm{C}_{3}$ & 0.082 & 0.174 & 0.146 \\
$\mathrm{C}_{4}$ & 0.003 & 0.006 & 0.209 \\
$\mathrm{C}_{5}$ & -0.105 & 0.109 & 0.250 \\
$\mathrm{C}_{6}$ & -0.006 & -0.003 & 0.291 \\
$\mathrm{C}_{7}$ & -0.173 & -0.079 & 0.354 \\
$\mathrm{C}_{8}$ & -0.013 & 0.169 & 0.451 \\
$\mathrm{C}_{9}$ & -0.134 & -0.078 & 0.468 \\
$\mathrm{O}_{1}$ & -0.011 & 0.272 & 0.110 \\
$\mathrm{O}_{2}$ & 0.322 & 0.143 & 0.158 \\
$\mathrm{O}_{3}$ & -0.149 & -0.323 & 0.342 \\
$\mathrm{O}_{4}$ & -0.269 & 0.017 & 0.390 \\
$\mathrm{~N}_{1}$ & -0.092 & 0.112 & 0.169 \\
$\mathrm{~N}_{2}$ & -0.109 & 0.095 & 0.331 \\
\hline
\end{tabular}

(b) 6,3-Polyurethane

\begin{tabular}{lrrl}
\hline Atom & \multicolumn{1}{c}{$x$} & \multicolumn{1}{c}{$y$} & $z$ \\
\hline $\mathrm{C}_{1}$ & -0.122 & -0.059 & 0.008 \\
$\mathrm{C}_{2}$ & 0.024 & 0.199 & 0.061 \\
$\mathrm{C}_{3}$ & -0.220 & 0.080 & 0.077 \\
$\mathrm{C}_{4}$ & 0.018 & 0.232 & 0.159 \\
$\mathrm{C}_{5}$ & -0.058 & 0.065 & 0.214 \\
$\mathrm{C}_{6}$ & -0.167 & 0.165 & 0.250 \\
$\mathrm{C}_{8}$ & -0.233 & -0.019 & 0.341 \\
$\mathrm{C}_{9}$ & -0.082 & 0.218 & 0.423 \\
$\mathrm{C}_{10}$ & -0.200 & -0.025 & 0.439 \\
$\mathrm{C}_{11}$ & 0.059 & 0.122 & 0.492 \\
$\mathrm{O}_{1}$ & -0.077 & 0.328 & 0.127 \\
$\mathrm{O}_{2}$ & 0.259 & 0.207 & 0.168 \\
$\mathrm{O}_{3}$ & -0.206 & -0.260 & 0.332 \\
$\mathrm{O}_{4}$ & -0.329 & 0.075 & 0.373 \\
$\mathrm{~N}_{1}$ & -0.155 & 0.168 & 0.180 \\
$\mathrm{~N}_{2}$ & -0.169 & 0.153 & 0.320 \\
\hline
\end{tabular}

of the molecules on the $a^{\prime} b^{\prime}$ plane perpendicular to the molecular axis from $z=0.0$ to 0.5 , where the methylene groups are omitted.

Table $\mathrm{V}$ lists the interatomic distances between the adjacent molecules. These distances are consistent with the corresponding intermolecular distances of the molecular crystals. The approach of two neighbouring methylene groups is hampered by two-dimensional hydrogen bonding perpendicular to the molecular axis. Hence the methylenemethylene distances are somewhat larger than those in the molecular crystals which crystallize by van 
(a) 4,3-Polyurethane

Table IV. Observed and calculated structure factors

\begin{tabular}{|c|c|c|c|c|c|c|c|c|c|c|c|c|c|c|}
\hline$h$ & $k$ & $l$ & $\left|F_{\text {obs }}\right|$ & $F_{\text {cal }}$ & $h$ & $k$ & $l$ & $\left|F_{\text {obs }}\right|$ & $F_{\text {cal }}$ & $h$ & $k$ & $l$ & $\left|F_{\text {obs }}\right|$ & $F_{\text {cal }}$ \\
\hline 1 & $\overline{1}$ & 0 & 14.6 & 19.5 & 0 & $\overline{1}$ & $3)$ & & 29.2 & 0 & $\overline{1}$ & 6) & & 0.4 \\
\hline 1 & 0 & $0)$ & & 81.1 & $\overline{1}$ & 0 & 3) & 49.6 & -29.5 & $\overline{1}$ & 0 & 6) & - & 0.4 \\
\hline 0 & 1 & $0)$ & 122.7 & 82.8 & 1 & $\overline{1}$ & $3)$ & & 24.0 & 0 & 0 & 6 & 9.9 & 14.5 \\
\hline 1 & 1 & 0 & 45.4 & 34.0 & $\overline{1}$ & 1 & 3) & 30.4 & -24.3 & $\overline{1}$ & $\overline{1}$ & 6 & 24.4 & -30.0 \\
\hline 2 & $\overline{2}$ & 0 & 13.1 & -15.8 & 1 & 0 & $3)$ & & 9.9 & 1 & $\overline{1}$ & $6)$ & & 22.1 \\
\hline 2 & 0 & 0 ) & & -9.9 & 0 & 1 & 3) & - & -9.4 & $\overline{1}$ & 1 & 6) & 25.9 & 22.2 \\
\hline 0 & 2 & 0) & 10.3 & -7.7 & $\overline{1}$ & $\overline{1}$ & 3 & - & -0.2 & 1 & $\overline{2}$ & $6)$ & & 17.9 \\
\hline 3 & $\overline{2}$ & $0)$ & 156 & -11.1 & 0 & $\overline{2}$ & 3) & - & 8.6 & $\overline{2}$ & 1 & 6 & 206 & 18.0 \\
\hline 2 & $\overline{3}$ & 0) & 15.0 & -13.1 & $\overline{2}$ & 0 & 3) & - & -8.6 & $\overline{2}$ & 0 & 6 & 20.6 & -4.5 \\
\hline 3 & $\overline{1}$ & 0 ) & & -8.0 & 2 & $\overline{2}$ & $\left.{ }^{3}\right)$ & & -16.1 & 0 & $\overline{2}$ & $6 /$ & & -5.0 \\
\hline$\overline{1}$ & 3 & 0) & 10.2 & -8.3 & $\overline{2}$ & 2 & 3 & & 14.7 & 1 & 0 & $6)$ & - & 4.5 \\
\hline 2 & 1 & $0)$ & & -9.6 & 2 & $\overline{1}$ & 3 & 44.7 & 23.5 & 0 & 1 & 6) & - & 4.7 \\
\hline 1 & 2 & $0)$ & 20.9 & 3.2 & $\overline{1}$ & 2 & $3 /$ & & -23.6 & 0 & $\overline{1}$ & $7)$ & & 25.1 \\
\hline 3 & $\overline{3}$ & 0 & 10.8 & 8.1 & 1 & 1 & 3 & - & -0.2 & $\overline{1}$ & 0 & 7) & 38.4 & -24.2 \\
\hline 3 & 0 & 0 ) & a & -2.8 & 0 & 0 & 4 & 47.3 & -33.8 & 0 & 0 & 7 & - & -0.1 \\
\hline 0 & 3 & 0) & $-a$ & -2.6 & $\overline{1}$ & 0 & 4) & - & -10.8 & $\overline{1}$ & $\overline{1}$ & 7 & - & -0.1 \\
\hline 0 & 0 & 1 & - & 0.3 & 0 & $\overline{1}$ & 4) & - & -10.7 & 1 & $\overline{1}$ & $7)$ & & 8.8 \\
\hline 0 & $\overline{1}$ & 1) & & 41.2 & 1 & $\overline{1}$ & 4) & & 14.4 & $\overline{1}$ & 1 & 7) & 11.8 & -5.7 \\
\hline$\overline{1}$ & 0 & 1) & 62.1 & -42.2 & $\overline{1}$ & 1 & 4) & 29.2 & 13.8 & 0 & $\overline{2}$ & $7)$ & $\ldots$ & 7.6 \\
\hline 1 & $\overline{1}$ & 1) & 816 & 52.9 & $\overline{1}$ & $\overline{1}$ & 4 & - & 9.5 & $\overline{2}$ & 0 & 7) & - & -7.7 \\
\hline$\overline{1}$ & 1 & 1) & 81.0 & -53.0 & 1 & 0 & $4)$ & & 10.1 & 1 & 0 & 7) & & 0.4 \\
\hline 1 & 0 & 1) & & 57.2 & 0 & 1 & 4) & 15.8 & 9.1 & 0 & 1 & 7) & - & -0.2 \\
\hline 0 & 1 & 1) & 90.5 & -55.4 & 2 & $\overline{1}$ & ${ }^{4} \backslash$ & & 17.7 & $\overline{3}$ & 1 & $7)$ & 206 & -21.3 \\
\hline$\overline{2}$ & 1 & $1)$ & - & -7.1 & $\overline{1}$ & 2 & 4 & 208 & 18.1 & 1 & $\overline{3}$ & 7) & 20.0 & 19.7 \\
\hline 1 & $\overline{2}$ & 1) & - & 7.2 & 2 & $\overline{2}$ & 4 & 20.8 & 8.3 & 2 & $\overline{3}$ & $7)$ & & 8.7 \\
\hline$\overline{1}$ & $\overline{1}$ & 1 & - & -0.5 & $\overline{2}$ & 2 & $4 /$ & & 8.5 & $\overline{3}$ & 2 & 7 & 150 & -8.7 \\
\hline$\overline{2}$ & 0 & 1) & - & -9.8 & $\overline{1}$ & $\overline{2}$ & ${ }^{4}$ & & 13.9 & 0 & $\overline{3}$ & 7 & 15.0 & -7.2 \\
\hline 0 & $\overline{2}$ & 1) & - & 9.6 & $\overline{2}$ & $\overline{1}$ & $4)$ & 170 & 13.3 & $\overline{3}$ & 0 & $7 /$ & & 7.4 \\
\hline 2 & 0 & 1) & 367 & 26.9 & $\frac{1}{2}$ & $\overline{3}$ & 4) & 17.0 & 8.7 & 1 & 1 & 7 & - & 0.3 \\
\hline 0 & 2 & 1) & 36.1 & -27.0 & $\overline{3}$ & 1 & 4 & & 8.9 & 0 & $\overline{1}$ & $8)$ & & 12.5 \\
\hline$\overline{2}$ & $\overline{1}$ & 1) & & 0.8 & 2 & 0 & ${ }^{4} \backslash$ & & 9.5 & $\overline{1}$ & 0 & 8) & 10.6 & 12.3 \\
\hline$\overline{1}$ & $\overline{2}$ & 1) & - & -0.9 & 0 & 2 & $4)$ & 11.5 & 9.4 & $\overline{1}$ & $\overline{1}$ & 8 & - & -3.5 \\
\hline 0 & 0 & 2 & - & -8.2 & $\overline{3}$ & 2 & 4 & 11.5 & 5.7 & 0 & 0 & 8 & 6.3 & -9.2 \\
\hline$\overline{1}$ & 0 & 2) & - & 9.9 & 2 & $\overline{3}$ & $4 /$ & & 5.8 & 0 & $\overline{2}$ & 8) & - & 5.4 \\
\hline 0 & $\overline{1}$ & 2) & - & 10.0 & 1 & 2 & $4)$ & - & 0.3 & $\overline{2}$ & 0 & 8) & - & 5.5 \\
\hline 1 & $\overline{1}$ & 2) & & -50.8 & 2 & 1 & 4) & - & 0.2 & 1 & $\overline{1}$ & $8)$ & - & -5.3 \\
\hline$\overline{1}$ & 1 & 2) & 79.7 & -64.3 & 0 & 0 & 5 & & 0.0 & $\overline{1}$ & 1 & 8) & - & -5.3 \\
\hline 1 & 0 & $2)$ & 210 & -22.6 & 0 & $\overline{1}$ & 5) & 4.7 & 6.8 & 1 & $\overline{2}$ & 8 ) & 231 & 15.9 \\
\hline 0 & 1 & 2) & 21.0 & -23.3 & $\overline{1}$ & 0 & 5) & & -6.7 & $\overline{2}$ & 1 & 8) & 23.1 & 15.7 \\
\hline 1 & $\overline{2}$ & 2) & 507 & 28.6 & 1 & $\overline{1}$ & 5 & - & 8.8 & $\overline{1}$ & $\overline{2}$ & $8)$ & - & -5.3 \\
\hline$\overline{2}$ & 1 & 2) & 50.7 & 28.0 & $\overline{1}$ & 1 & 5) & - & -8.1 & $\overline{2}$ & $\overline{1}$ & 8) & - & -5.3 \\
\hline 2 & $\overline{1}$ & $2)$ & - & 2.2 & $\overline{1}$ & $\overline{1}$ & 5 & - & -0.3 & 0 & $\overline{1}$ & 9 ) & 177 & -10.5 \\
\hline$\overline{1}$ & 2 & 2) & - & 2.0 & $\overline{2}$ & 1 & $5)$ & - & -1.1 & $\overline{1}$ & 0 & 9) & 11.1 & 10.2 \\
\hline 0 & $\overline{2}$ & 2) & $\overline{-1}$ & 7.8 & 1 & $\overline{2}$ & 5) & - & 1.1 & $\overline{1}$ & $\overline{1}$ & 9 & - & 0.0 \\
\hline$\overline{2}$ & 0 & 2) & - & 7.5 & 1 & 0 & 5 & & -15.3 & 0 & 0 & 9 & - & 0.3 \\
\hline 1 & 1 & 2 & - & -9.2 & 0 & 1 & 5 & 26.6 & 14.7 & 1 & $\overline{1}$ & ${ }^{9} \backslash$ & & 12.0 \\
\hline 2 & 0 & 2) & & 6.4 & $\overline{2}$ & 0 & 5 & 20.0 & -6.5 & $\overline{1}$ & 1 & 9 & 27.7 & -12.2 \\
\hline 0 & 2 & 2) & 16.6 & -8.4 & 0 & $\overline{2}$ & $5^{\prime}$ & & 6.8 & 1 & $\overline{2}$ & 9 & & -2.2 \\
\hline$\overline{2}$ & $\overline{1}$ & $2)$ & - & -7.9 & $\overline{2}$ & $\overline{1}$ & $5)$ & & 5.6 & $\overline{2}$ & 1 & $9 /$ & & 2.4 \\
\hline$\overline{1}$ & $\overline{2}$ & 2) & - & -7.7 & $\overline{1}$ & $\overline{2}$ & 5) & - & -5.8 & & & & & \\
\hline 0 & 0 & 3 & - & 0.4 & & & & & & & & & & \\
\hline
\end{tabular}


Structural Studies on Linear Polyurethanes

Table IV (a) continued.

\begin{tabular}{|c|c|c|c|c|c|c|c|c|c|c|c|c|c|c|}
\hline$h$ & $k$ & $l$ & $\left|F_{\text {obs }}\right|$ & $F_{\text {cal }}$ & $h$ & $k$ & $l$ & $\left|F_{\text {obs }}\right|$ & $F_{\text {cal }}$ & $h$ & $k$ & $l$ & $\left|F_{\text {obs }}\right|$ & $F_{\text {cal }}$ \\
\hline 2 & $\overline{1}$ & $9)$ & & 9.1 & 1 & $\begin{array}{ll}1 & 1\end{array}$ & $11)$ & & 6.6 & 0 & $\overline{2}$ & 13) & & 11.9 \\
\hline$\overline{1}$ & 2 & 9 & & -9.7 & $\overline{1}$ & 11 & 11) & 6.6 & -6.2 & $\overline{2}$ & 0 & 13) & - & -12.4 \\
\hline 2 & $\overline{3}$ & 9 & 15.1 & -1.8 & 0 & 11 & 11 & & 1.0 & 0 & 0 & 13 & - & 0.5 \\
\hline$\overline{3}$ & 2 & $9 /$ & & 1.7 & 1 & $\begin{array}{ll}0 & 1\end{array}$ & 11) & - & -0.9 & $\overline{2}$ & 1 & $13)$ & 221 & 11.4 \\
\hline 1 & 1 & 9 & - & 0.6 & $\overline{1}$ & $\begin{array}{ll}\overline{1} & 1\end{array}$ & 12 & - & 0.7 & 1 & $\overline{2}$ & 13) & 22.1 & -15.3 \\
\hline 0 & $\overline{1}$ & $10)$ & - & -10.0 & 0 & $\begin{array}{ll}1 & 1\end{array}$ & $12)$ & & -13.0 & 1 & $\overline{1}$ & 13 & & 2.6 \\
\hline$\overline{1}$ & 0 & $10)$ & - & -10.2 & $\overline{1}$ & $\begin{array}{ll}0 & 1\end{array}$ & $12)$ & 15.9 & -11.3 & $\overline{1}$ & 1 & 13) & - & -3.5 \\
\hline$\overline{1}$ & $\overline{1}$ & 10 & 14.5 & 17.5 & 0 & $\overline{2} 1$ & $12)$ & & -25.3 & $\overline{1}$ & $\overline{1}$ & 14 & & 5.9 \\
\hline 0 & $\overline{2}$ & 10 & & 16.3 & $\overline{2}$ & $\begin{array}{ll}0 & 1\end{array}$ & 12) & 26.5 & -25.0 & 0 & $\overline{1}$ & $14)$ & & 9.4 \\
\hline$\overline{2}$ & 0 & 10 & 16.9 & 16.1 & 0 & 01 & 12 & - & 2.5 & $\overline{1}$ & 0 & 14) & - & 8.5 \\
\hline 0 & 0 & 10 & & -2.9 & $\overline{1}$ & $\overline{2} 1$ & $12)$ & $\ldots$ & 8.1 & 0 & $\overline{2}$ & $14)$ & & 10.0 \\
\hline 1 & $\overline{1}$ & 10 & & -12.8 & $\overline{2}$ & $\begin{array}{ll}\overline{1} & 1\end{array}$ & 12) & - & 7.8 & $\overline{2}$ & 0 & 14) & 9.5 & 9.9 \\
\hline$\overline{1}$ & 1 & 10 & 208 & -13.4 & 1 & $\begin{array}{ll}\overline{2} & 1\end{array}$ & $12)$ & & -10.8 & $\overline{2}$ & $\overline{1}$ & $14)$ & & 8.1 \\
\hline 1 & $\overline{2}$ & 10 & 20.8 & 0.3 & $\overline{2}$ & 11 & 12) & - & -10.9 & $\overline{1}$ & $\overline{2}$ & 14) & 9.6 & 8.0 \\
\hline$\overline{2}$ & 11 & $10 /$ & & -0.3 & 1 & $\overline{1} 1$ & $12)$ & & -6.8 & 0 & 0 & 14 & - & -5.7 \\
\hline 1 & $\overline{2}$ & $10)$ & - & 10.4 & $\overline{1}$ & 11 & 12) & - & -6.3 & $\overline{1}$ & 1 & 14 & & 4.9 \\
\hline$\overline{2}$ & $\overline{1} 1$ & 10) & - & 10.5 & 1 & $\overline{3} 1$ & 12 & & -9.4 & 1 & $\overline{1}$ & 14 & & 6.1 \\
\hline$\overline{1}$ & $\overline{1} 1$ & 11 & - & -0.2 & $\overline{3}$ & 11 & 12 & & -9.8 & 1 & $\overline{3}$ & 14 & 8.8 & 3.8 \\
\hline 0 & $\overline{1} 1$ & $11)$ & - & -7.1 & 0 & $\overline{3} 1$ & 12 & 16.6 & -15.5 & $\overline{3}$ & 1 & 14 & & 4.0 \\
\hline$\overline{1}$ & 0 & 11) & & 6.9 & $\overline{3}$ & $\begin{array}{ll}0 & 1\end{array}$ & $12 /$ & & -15.6 & 0 & 1 & $14)$ & $\ldots$ & -7.4 \\
\hline 0 & $\overline{2}$ & $11)$ & 141 & -10.0 & 0 & 11 & $12)$ & $\ldots$ & -2.7 & 1 & 0 & 14) & - & -8.3 \\
\hline$\overline{2}$ & 0 & 11) & 14.1 & 10.0 & 1 & $\begin{array}{ll}0 & 1\end{array}$ & 12) & - & -2.7 & & & & & \\
\hline 0 & 0 & 11 & - & 0.1 & $\overline{1}$ & $\begin{array}{ll}\overline{1} & 1\end{array}$ & 13 & - & 0.4 & & & & & \\
\hline 1 & $\overline{2}$ & $11)$ & 294 & 13.0 & 0 & $\overline{1} 1$ & $13)$ & 153 & 17.9 & & & & & \\
\hline 2 & $\overline{1} 1$ & 11) & 29.4 & -12.2 & $\overline{1}$ & 01 & 13) & 15.3 & -17.2 & & & & & \\
\hline
\end{tabular}

(b) 6,3-Polyurethane

\begin{tabular}{|c|c|c|c|c|c|c|c|c|c|c|c|c|c|c|}
\hline$h$ & $k$ & $l$ & $\left|F_{\text {obs }}\right|$ & $F_{\text {cal }}$ & $h$ & $k$ & $l$ & $\left|F_{\text {obs }}\right|$ & $F_{\text {cal }}$ & $h$ & $k$ & $l$ & $\left|F_{\text {obs }}\right|$ & $F_{\text {cal }}$ \\
\hline 1 & $\overline{1}$ & 0 & 19.7 & -25.3 & 2 & 0 & 1) & \multirow{2}{*}{52.1} & 20.5 & $\overline{1}$ & 0 & 3) & \multirow[b]{2}{*}{58.1} & -39.1 \\
\hline 1 & 0 & $0)$ & \multirow{2}{*}{114.4} & 77.0 & 0 & 2 & 1) & & -21.8 & 0 & $\overline{1}$ & 3) & & 38.8 \\
\hline 0 & 1 & $0)$ & & 79.4 & $\overline{1}$ & $\overline{2}$ & 1) & & 3.4 & 1 & $\overline{1}$ & $3)$ & \multirow[b]{2}{*}{60.6} & 35.2 \\
\hline 1 & $\overline{2}$ & 0 & \multirow{2}{*}{37.5} & -27.3 & $\overline{2}$ & $\overline{1}$ & 1) & - & -3.6 & $\overline{1}$ & 1 & $3)$ & & -35.1 \\
\hline$\overline{2}$ & 1 & $0)$ & & -26.6 & 0 & 0 & 2 & - & -6.5 & 1 & 0 & $3)$ & \multirow{2}{*}{29.1} & -13.9 \\
\hline 1 & 1 & 0 & \multirow[t]{2}{*}{49.9} & 34.8 & $\overline{1}$ & 0 & 2) & \multirow{2}{*}{49.3} & 37.9 & 0 & 1 & $3)$ & & 13.9 \\
\hline 2 & $\overline{2}$ & $0)$ & & 16.9 & 0 & $\overline{1}$ & 2) & & 37.9 & $\overline{1}$ & $\overline{1}$ & 3 & - & -0.4 \\
\hline 2 & 0 & 0 & \multirow[t]{2}{*}{46.0} & -30.3 & 1 & $\overline{1}$ & 2) & \multirow{2}{*}{102.7} & 57.8 & $\overline{2}$ & 1 & $3)$ & \multirow{2}{*}{30.4} & -6.1 \\
\hline 0 & 2 & 0 ) & & -29.4 & $\overline{1}$ & 1 & 2) & & 57.5 & 1 & $\overline{2}$ & 3) & & 15.9 \\
\hline 1 & 2 & $0)$ & \multirow{2}{*}{20.1} & -6.7 & 1 & 0 & 2) & \multirow{2}{*}{32.2} & -22.2 & 0 & $\overline{2}$ & $3)$ & \multirow[b]{2}{*}{-} & 10.2 \\
\hline 2 & 1 & $0)$ & & -7.5 & 0 & 1 & 2) & & -23.3 & $\overline{2}$ & 0 & 3) & & -9.9 \\
\hline 3 & 0 & $0)$ & \multirow[b]{2}{*}{-} & -6.9 & $\overline{1}$ & $\overline{1}$ & 2) & \multirow{3}{*}{55.0} & 23.5 & 2 & $\overline{1}$ & $3)$ & \multirow{2}{*}{31.8} & -23.1 \\
\hline 0 & 3 & $0)$ & & -7.0 & $\overline{2}$ & 1 & 2 & & 23.5 & $\overline{1}$ & 2 & 3) & & 22.9 \\
\hline 0 & 0 & 1 & - & 0.1 & 1 & $\overline{2}$ & $2)$ & & 23.7 & 1 & 1 & 3 & - & -0.5 \\
\hline$\overline{1}$ & 0 & 1) & \multirow{2}{*}{92.6} & -66.1 & 1 & 1 & 2 & - & -9.2 & 0 & 0 & 4 & 46.6 & -35.7 \\
\hline 0 & $\overline{1}$ & 1) & & 65.5 & $\overline{2}$ & 0 & 2) & & 8.3 & $\overline{1}$ & 0 & $4)$ & \multirow{2}{*}{-} & -9.3 \\
\hline 1 & $\overline{1}$ & 1) & \multirow{2}{*}{74.8} & 63.1 & 0 & $\overline{2}$ & 2) & & 8.2 & 0 & $\overline{1}$ & 4) & & -9.7 \\
\hline$\overline{1}$ & 1 & 1) & & -63.2 & 2 & 0 & 2) & \multirow{2}{*}{34.0} & 22.9 & 1 & $\overline{1}$ & $4)$ & \multirow{3}{*}{25.9} & 17.6 \\
\hline 1 & 0 & 1) & \multirow{2}{*}{146.3} & 85.2 & 0 & 2 & 2) & & 22.4 & $\overline{1}$ & 1 & 4) & & 17.6 \\
\hline 0 & 1 & 1) & & -84.5 & $\overline{2}$ & $\overline{1}$ & 2) & & -4.7 & $\overline{1}$ & $\overline{1}$ & $4)$ & & 4.8 \\
\hline$\overline{1}$ & $\overline{1}$ & 1 & - & -0.5 & $\overline{1}$ & $\overline{2}$ & 2) & - & -4.6 & 1 & 0 & 4 & \multirow[t]{2}{*}{32.8} & 21.0 \\
\hline 1 & 1 & 1 & - & 1.1 & 0 & 0 & 3 & - & 0.1 & 0 & 1 & $4)$ & & 20.6 \\
\hline
\end{tabular}


Y. SAITO, K. HARA, and S. KinOShita

Table IV (b), continued.

\begin{tabular}{|c|c|c|c|c|c|c|c|c|c|c|c|c|c|c|}
\hline$h$ & $k$ & $l$ & $\left|F_{\text {obs }}\right|$ & $F_{\text {cal }}$ & $h$ & $k$ & $l$ & $\left|F_{\text {obs }}\right|$ & $F_{\text {cal }}$ & $h$ & $k$ & $l$ & $\left|F_{\text {obs }}\right|$ & $F_{\text {cal }}$ \\
\hline$\overline{1}$ & 2 & $4)$ & 438 & 22.1 & 1 & 0 & $8)$ & - & -7.9 & $\overline{2}$ & $\begin{array}{ll}\overline{1} & 1\end{array}$ & $11)$ & & -8.3 \\
\hline 2 & $\overline{1}$ & 4) & 43.8 & 22.5 & 0 & 1 & 8) & - & -7.9 & $\overline{1}$ & $\overline{2} 1$ & 11) & - & 8.1 \\
\hline$\overline{2}$ & 2 & $4)$ & & -24.4 & 1 & $\overline{1}$ & $8)$ & & -11.4 & 0 & $\begin{array}{ll}\overline{1} & 1\end{array}$ & $12)$ & & 7.9 \\
\hline 2 & $\overline{2}$ & 4) & 44.7 & -24.9 & $\overline{1}$ & 1 & 8) & - & -11.7 & $\overline{1}$ & $\begin{array}{ll}0 & 1\end{array}$ & 12) & - & 8.0 \\
\hline 1 & 1 & 4 & - & 7.9 & 2 & $\overline{1}$ & $8)$ & & 15.8 & $\overline{1}$ & $\begin{array}{ll}\overline{1} & 1\end{array}$ & 12 & 19.3 & -22.1 \\
\hline 2 & $\overline{3}$ & $4)$ & & -21.0 & $\overline{1}$ & 2 & 8 & & 14.9 & 0 & $\begin{array}{ll}0 & 1\end{array}$ & 12 & - & 9.5 \\
\hline$\overline{3}$ & 2 & 4) & 26.2 & -21.0 & 1 & $\overline{3}$ & 8 & 30.6 & 6.6 & $\overline{2}$ & $\begin{array}{ll}0 & 1\end{array}$ & $12)$ & 205 & -16.5 \\
\hline$\overline{3}$ & 0 & $4)$ & - & 8.3 & $\overline{3}$ & 1 & $8 /$ & & 7.1 & 0 & $\begin{array}{ll}\overline{2} & 1\end{array}$ & 12) & 20.5 & -16.6 \\
\hline 0 & $\overline{3}$ & 4) & - & 8.6 & 1 & $\overline{4}$ & $8)$ & & -6.8 & 1 & $\begin{array}{ll}\overline{1} & 1\end{array}$ & $12)$ & & 18.6 \\
\hline 0 & 0 & 5 & - & -0.1 & $\overline{4}$ & 1 & 8 & & -6.0 & $\overline{1}$ & 11 & 12) & 36.2 & 18.7 \\
\hline$\overline{1}$ & 0 & $5)$ & - & -1.8 & 2 & $\overline{4}$ & 8 & 20.1 & 9.0 & $\overline{2}$ & $\begin{array}{ll}\overline{1} & 1\end{array}$ & $12)$ & & -9.0 \\
\hline 0 & $\overline{1}$ & 5) & - & 1.8 & $\overline{4}$ & 2 & $8 /$ & & 9.1 & $\overline{1}$ & $\begin{array}{ll}2 & 1\end{array}$ & 12) & - & -9.2 \\
\hline 1 & $\overline{1}$ & $5)$ & & 9.1 & 1 & 2 & $8)$ & - & 2.5 & 0 & $\begin{array}{ll}\overline{1} & 1\end{array}$ & $13)$ & & 8.5 \\
\hline$\overline{1}$ & 1 & 5) & 18.5 & -8.9 & 2 & 1 & 8) & - & 1.9 & $\overline{1}$ & $\begin{array}{ll}0 & 1\end{array}$ & 13) & - & -8.5 \\
\hline$\overline{1}$ & $\overline{1}$ & 5 & - & 0.4 & 0 & $\overline{1}$ & 9) & & -15.9 & $\overline{1}$ & $\begin{array}{ll}\overline{1} & 1\end{array}$ & 13 & - & -0.3 \\
\hline 1 & 0 & $5)$ & 24.5 & -15.6 & $\overline{1}$ & 0 & 9) & 29.8 & 15.4 & 0 & $\overline{2} 1$ & $13)$ & & -18.6 \\
\hline 0 & 1 & 5) & $24 . J$ & 15.7 & 0 & 0 & 9 & - & 0.0 & $\overline{2}$ & $\begin{array}{ll}0 & 1\end{array}$ & 13) & 35.4 & 20.5 \\
\hline$\overline{2}$ & 0 & $5)$ & & -12.3 & $\overline{1}$ & $\overline{1}$ & 9 & - & 0.3 & 0 & $\begin{array}{ll}0 & 1\end{array}$ & 13 & - & 0.0 \\
\hline 0 & $\overline{2}$ & 5) & 23.0 & 12.5 & 1 & $\overline{1}$ & ${ }^{9}$ & & -9.7 & 1 & $\begin{array}{ll}\overline{1} & 1\end{array}$ & $13)$ & $\ldots$ & -7.9 \\
\hline$\overline{1}$ & 2 & $5)$ & - & -5.1 & $\overline{1}$ & 1 & 9 & & 9.7 & $\overline{1}$ & 11 & 13) & - & 7.8 \\
\hline 2 & $\overline{1}$ & 5) & - & 5.1 & $\overline{2}$ & 0 & 9 & 19.0 & -13.1 & 0 & $\begin{array}{ll}\overline{3} & 1\end{array}$ & $13)$ & & -12.5 \\
\hline 0 & 0 & 6 & 45.2 & 44.7 & 0 & $\overline{2}$ & $9 /$ & & 12.2 & $\overline{3}$ & $\begin{array}{ll}0 & 1\end{array}$ & 13) & 21.7 & 12.7 \\
\hline$\overline{1}$ & 0 & $6)$ & - & 7.9 & 1 & $\overline{2}$ & 9) & 16.0 & 16.3 & 0 & 11 & $13)$ & $\overline{-}$ & 5.4 \\
\hline 0 & $\overline{1}$ & $6)$ & - & 7.7 & $\overline{2}$ & 1 & 9) & 16.0 & -16.1 & 1 & $\begin{array}{ll}0 & 1\end{array}$ & 13) & - & -5.5 \\
\hline 1 & $\overline{1}$ & $6)$ & & 27.0 & 1 & 0 & $9)$ & - & 0.2 & $\overline{1}$ & $\begin{array}{ll}\overline{1} & 1\end{array}$ & 14 & - & -5.1 \\
\hline$\overline{1}$ & 1 & 6) & 24.8 & 26.8 & 0 & 1 & 9) & - & -0.5 & 0 & $\begin{array}{ll}\overline{1} & 1\end{array}$ & $14)$ & 225 & 18.4 \\
\hline$\overline{1}$ & $\overline{1}$ & 6 & - & -11.0 & 0 & $\overline{1}$ & $10)$ & & -12.9 & $\overline{1}$ & $\begin{array}{ll}0 & 1\end{array}$ & 14) & 22.3 & 18.4 \\
\hline 1 & 0 & $6)$ & - & 7.8 & $\overline{1}$ & 0 & $10)$ & 16.4 & -13.0 & 0 & $\begin{array}{ll}0 & 1\end{array}$ & 14 & - & 3.1 \\
\hline 0 & 1 & $6)$ & - & 8.5 & $\overline{1}$ & $\overline{1}$ & 10 & - & 9.5 & 1 & $\overline{2} 1$ & $14)$ & 302 & 20.7 \\
\hline 1 & 1 & 6 & - & 6.8 & 0 & 0 & 10 & 17.0 & -13.5 & $\overline{2}$ & 11 & 14) & 30.2 & 17.4 \\
\hline 2 & $\overline{3}$ & $6)$ & 25.9 & 15.9 & $\overline{1}$ & 1 & $10)$ & - & 10.1 & $\overline{2}$ & 21 & $14)$ & 16.7 & -11.2 \\
\hline$\overline{3}$ & 2 & $6)$ & 25.9 & 18.0 & 1 & $\overline{1}$ & $10)$ & - & 9.9 & 2 & $\overline{2} 1$ & 14) & 10.1 & -11.2 \\
\hline 2 & 0 & $6)$ & - & -6.9 & 1 & $\overline{2}$ & $10)$ & 24.5 & -6.2 & $\overline{1}$ & 21 & $14)$ & - & -5.3 \\
\hline 0 & 2 & $6)$ & & -6.8 & $\overline{2}$ & 1 & $10)$ & 24.5 & -5.9 & 2 & $\begin{array}{ll}1 & 1\end{array}$ & 14) & - & -5.7 \\
\hline 0 & $\overline{1}$ & $7)$ & & -11.4 & 1 & 0 & $10)$ & - & 5.5 & $\overline{1}$ & $\begin{array}{ll}\overline{1} & 1\end{array}$ & 15 & - & 0.2 \\
\hline$\overline{1}$ & 0 & 7) & 24.5 & 11.2 & 0 & 1 & $10)$ & & 5.3 & 0 & $\begin{array}{ll}\overline{1} & 1\end{array}$ & $15)$ & 166 & -12.8 \\
\hline 0 & 0 & 7 & - & 0.1 & 1 & $\overline{3}$ & $10 \backslash$ & & 11.8 & $\overline{1}$ & $\begin{array}{ll}0 & 1\end{array}$ & 15) & 10.0 & 12.8 \\
\hline$\overline{1}$ & $\overline{1}$ & 7 & - & 0.4 & $\overline{3}$ & 1 & 10 & 267 & 11.8 & 0 & $\overline{2} 1$ & $15)$ & 241 & 15.4 \\
\hline 1 & $\overline{1}$ & $7)$ & 32.4 & 22.9 & 2 & $\overline{2}$ & 10 & 20.1 & 5.6 & $\overline{2}$ & $\begin{array}{ll}0 & 1\end{array}$ & 15) & 24.1 & -16.0 \\
\hline 1 & 1 & 7) & 52.4 & -22.9 & $\overline{2}$ & 2 & $10 /$ & & 5.7 & 0 & $\begin{array}{ll}0 & 1\end{array}$ & 15 & - & -0.2 \\
\hline 1 & $\overline{2}$ & $7)$ & 28.9 & 27.6 & 2 & $\overline{3}$ & $10)$ & 21.7 & -8.6 & $\frac{1}{1}$ & $\overline{2} 1$ & $15)$ & 17.8 & 16.0 \\
\hline 2 & 1 & 7) & 28.9 & -27.7 & $\overline{3}$ & 2 & $10)$ & 21.1 & -9.3 & $\overline{2}$ & 11 & 15) & 17.0 & -16.0 \\
\hline 1 & 0 & $7)$ & 24.2 & 19.1 & 1 & 1 & 10 & - & -0.8 & $\overline{1}$ & 11 & 15 & 147 & -6.1 \\
\hline 0 & 1 & 7) & 24.2 & -18.9 & 0 & $\overline{1}$ & $11)$ & 9.1 & -5.7 & 1 & $\begin{array}{ll}\overline{1} & 1\end{array}$ & 15) & 14.1 & 6.7 \\
\hline 3 & $\overline{3}$ & $7)$ & 21.0 & 9.0 & $\overline{1}$ & 0 & 11) & 9.1 & 6.0 & 1 & $\overline{3} 1$ & 15 & & 7.2 \\
\hline$\overline{3}$ & 3 & 7) & 21.0 & -8.9 & $\overline{1}$ & $\overline{1}$ & 11 & - & -0.3 & $\overline{3}$ & 11 & 15 & 204 & -6.7 \\
\hline 1 & 2 & $7)$ & - & -8.2 & 0 & 0 & 11 & - & -0.2 & $\overline{3}$ & $\begin{array}{ll}0 & 1\end{array}$ & 15 & 20.4 & -13.9 \\
\hline 2 & 1 & 7) & - & -8.3 & 0 & $\overline{2}$ & $11)$ & & 14.4 & 0 & $\begin{array}{ll}\overline{3} & 1\end{array}$ & $15^{\prime}$ & & 13.9 \\
\hline 0 & $\overline{1}$ & $8)$ & 17.1 & 15.0 & $\overline{2}$ & 0 & 11) & 20.3 & -14.1 & 0 & 11 & $15)$ & - & -6.8 \\
\hline 1 & 0 & $8)$ & 17.1 & 14.8 & $\overline{2}$ & 1 & $11)$ & 343 & 30.3 & 1 & $\begin{array}{ll}0 & 1\end{array}$ & 15) & 一 & 6.8 \\
\hline 0 & 0 & 8 & - & -7.6 & 1 & $\overline{2}$ & 11) & 34.3 & -30.0 & & & & & \\
\hline$\overline{1}$ & $\overline{1}$ & 8 & 17.9 & 22.2 & & & & & & & & & & \\
\hline
\end{tabular}


Structural Studies on Linear Polyurethanes

Table IV (b) continued.

\begin{tabular}{|c|c|c|c|c|c|c|c|c|c|c|c|c|c|}
\hline$h$ & $k \quad l$ & $\left|F_{\text {obs }}\right|$ & $F_{\text {cal }}$ & $h$ & $k$ & $l$ & $\left|F_{\text {obs }}\right|$ & $F_{\text {cal }}$ & $h$ & $k$ & $l$ & $\left|F_{\text {obs }}\right|$ & $F_{\text {cal }}$ \\
\hline$\overline{1}$ & $\begin{array}{ll}\overline{1} & 16\end{array}$ & - & -9.0 & $\overline{1}$ & $\overline{2} \quad 16$ & & \multirow[b]{2}{*}{19.8} & -4.0 & 1 & $\overline{1}$ & 16) & & -4.0 \\
\hline 0 & $\overline{1} \quad 16$ & \multirow{2}{*}{16.5} & -16.0 & $\overline{2}$ & $\overline{1} 16$ & & & -3.8 & $\overline{1}$ & 1 & 16) & & -3.9 \\
\hline$\overline{1}$ & $\begin{array}{ll}0 & 16\end{array}$ & & -15.9 & 0 & 016 & & - & 6.7 & $\overline{3}$ & 1 & $16)$ & \multirow{2}{*}{12.8} & 6.6 \\
\hline 0 & $\overline{2} 16$ & \multirow{3}{*}{11.7} & -8.0 & $\overline{2}$ & 116 & & & -7.5 & 1 & $\overline{3}$ & 16) & & 6.7 \\
\hline$\overline{2}$ & $\begin{array}{ll}0 & 16\end{array}$ & & -8.0 & 1 & 216 & 5) & 14.6 & -7.5 & 0 & 1 & $16)$ & \multirow{2}{*}{-} & 3.0 \\
\hline & & & & & & & & & 1 & 0 & 16) & & 3.2 \\
\hline
\end{tabular}

a - , unobserved reflection.

(a)

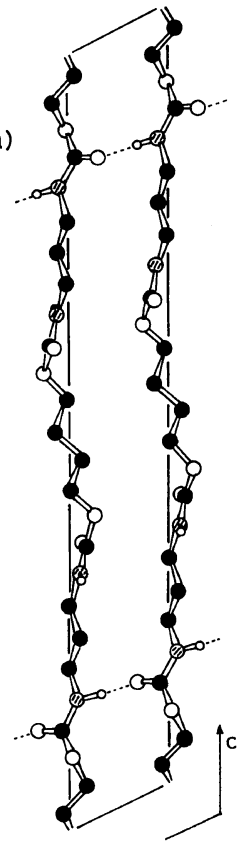

( $1 \overline{2} 0)$

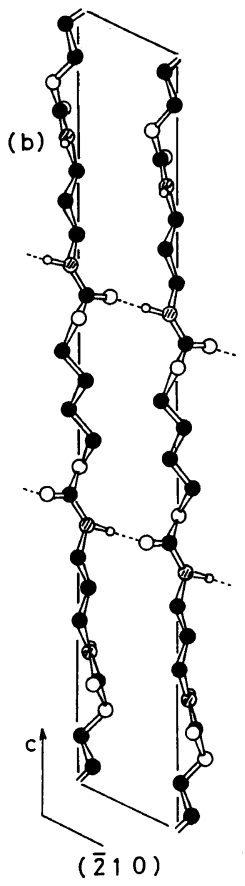

(c)

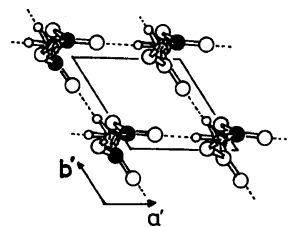

Figure 7. Crystal structure of 4,3-polyurethane: (a)

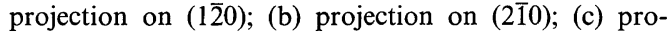
jection along $c$-axis; methylene groups omitted.

der Waals forces.

Comparison with Other Members of $m, n$-Polyurethanes

Polyurethanes with $m, n=$ even have the confor-

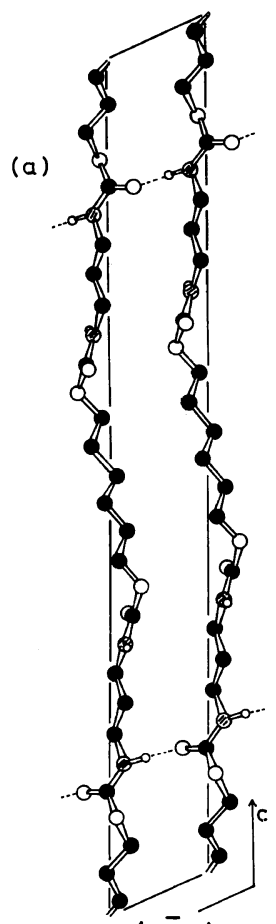

$(1 \overline{2} 0)$

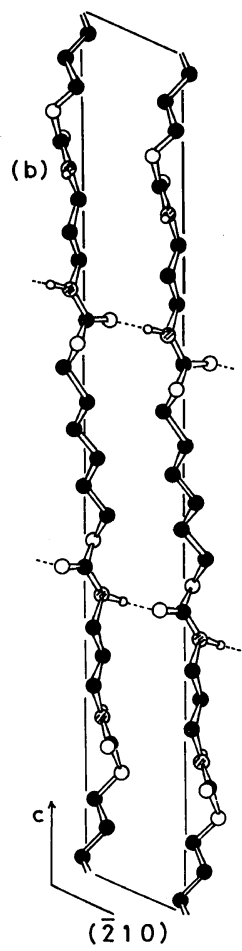

(c)

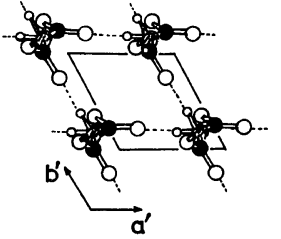

Figure 8. Crystal structure of 6,3-polyurethane: (a) projection on (120); (b) projection on ( $\overline{2} 10)$; (c) projection along $c$-axis; methylene groups omitted.

mation of an extended planer zig-zag, and their fiber identity periods differ from one another by the length of the methylene sequences of the glycols. 
Table V. Intermolecular atomic distances

(a) 4,3-Polyurethane

\begin{tabular}{lclccc}
\hline Atom pair & Distance $/ \AA$ & Atom pair & Distance $/ \AA$ & Atom pair & Distance $/ \AA$ \\
\hline $\mathrm{C}_{1}-\mathrm{C}_{2}(2)^{\mathrm{a}}$ & 3.92 & $\mathrm{C}_{5}-\mathrm{C}_{6}(3)$ & 3.96 & $\mathrm{C}_{3}-\mathrm{C}_{6}(4)$ & 3.95 \\
$\mathrm{C}_{1}-\mathrm{O}_{1}(2)$ & 3.93 & $\mathrm{C}_{5}-\mathrm{O}_{3}(3)$ & 3.30 & $\mathrm{O}_{2}-\mathrm{C}_{4}(4)$ & 3.74 \\
$\mathrm{O}_{2}-\mathrm{C}_{3}(2)$ & 3.95 & $\mathrm{C}_{6}-\mathrm{O}_{3}(3)$ & 3.63 & $\mathrm{O}_{2}-\mathrm{C}_{5}(4)$ & 3.74 \\
$\mathrm{O}_{2}-\mathrm{N}_{1}(2)^{\mathrm{b}}$ & 2.92 & $\mathrm{~N}_{2}-\mathrm{O}_{3}(3)^{\mathrm{b}}$ & 2.91 & $\mathrm{O}_{2}-\mathrm{C}_{6}(4)$ & 3.59 \\
$\mathrm{O}_{2}-\mathrm{C}_{4}(2)$ & 3.61 & $\mathrm{C}_{7}-\mathrm{O}_{3}(3)$ & 3.92 & $\mathrm{C}_{4}-\mathrm{C}_{7}(4)$ & 3.95 \\
$\mathrm{O}_{2}-\mathrm{C}_{5}(2)$ & 3.26 & $\mathrm{O}_{4}-\mathrm{C}_{9}(3)$ & 3.92 & $\mathrm{C}_{4}-\mathrm{O}_{3}(4)$ & 3.57 \\
$\mathrm{C}_{4}-\mathrm{C}_{5}(2)$ & 3.98 & $\mathrm{C}_{8}-\mathrm{C}_{9}(3)$ & 3.92 & $\mathrm{C}_{5}-\mathrm{C}_{7}(4)$ & 3.85 \\
$\mathrm{C}_{6}-\mathrm{O}_{4}(2)$ & 3.71 & $\mathrm{C}_{8}-\mathrm{C}_{9}{ }^{\prime}(3)^{\mathrm{c}}$ & 3.92 & $\mathrm{C}_{5}-\mathrm{O}_{3}(4)$ & 3.70 \\
$\mathrm{O}_{3}-\mathrm{O}_{4}(2)$ & 3.59 & $\mathrm{C}_{8}-\mathrm{C}_{8}{ }^{\prime}(3)$ & 3.83 & $\mathrm{C}_{5}-\mathrm{O}_{4}(4)$ & 3.92 \\
$\mathrm{O}_{1}-\mathrm{O}_{2}(3)$ & 3.55 & $\mathrm{O}_{1}-\mathrm{C}_{5}(4)$ & 3.92 & $\mathrm{C}_{6}-\mathrm{O}_{3}(4)$ & 3.73 \\
$\mathrm{O}_{1}-\mathrm{C}_{4}(3)$ & 3.73 & $\mathrm{C}_{3}-\mathrm{C}_{5}(4)$ & 3.86 & & \\
\hline
\end{tabular}

(b) 6,3-Polyurethane

\begin{tabular}{lcllll}
\hline Atom pair & Distance $/ \AA$ & Atom pair & Distance $/ \AA$ & Atom pair & Distance $/ \AA$ \\
\hline $\mathrm{C}_{1}-\mathrm{C}_{3}(2)$ & 3.98 & $\mathrm{O}_{1}-\mathrm{C}_{5}(3)$ & 3.81 & $\mathrm{C}_{11}-\mathrm{C}_{11}^{\prime}(3)$ & 3.94 \\
$\mathrm{C}_{2}-\mathrm{C}_{3}(2)$ & 3.94 & $\mathrm{C}_{6}-\mathrm{O}_{3}(3)$ & 3.38 & $\mathrm{C}_{4}-\mathrm{C}_{6}(4)$ & 3.98 \\
$\mathrm{C}_{2}-\mathrm{O}_{1}(2)$ & 3.97 & $\mathrm{C}_{7}-\mathrm{O}_{3}(3)$ & 3.67 & $\mathrm{O}_{2}-\mathrm{C}_{5}(4)$ & 3.73 \\
$\mathrm{O}_{2}-\mathrm{C}_{4}(2)$ & 3.91 & $\mathrm{~N}_{2}-\mathrm{O}_{3}(3)^{\mathrm{b}}$ & 2.92 & $\mathrm{O}_{2}-\mathrm{C}_{6}(4)$ & 3.81 \\
$\mathrm{O}_{2}-\mathrm{N}_{1}(2)^{\mathrm{b}}$ & 2.93 & $\mathrm{C}_{8}-\mathrm{O}_{3}(3)$ & 3.91 & $\mathrm{O}_{2}-\mathrm{C}_{7}(4)$ & 3.77 \\
$\mathrm{O}_{2}-\mathrm{C}_{5}(2)$ & 3.68 & $\mathrm{O}_{4}-\mathrm{C}_{10}(3)$ & 3.97 & $\mathrm{C}_{5}-\mathrm{O}_{3}(4)$ & 3.78 \\
$\mathrm{O}_{2}-\mathrm{C}_{6}(2)$ & 3.39 & $\mathrm{C}_{9}-\mathrm{C}_{10}(3)$ & 3.94 & $\mathrm{C}_{6}-\mathrm{C}_{8}(4)$ & 3.98 \\
$\mathrm{C}_{7}-\mathrm{O}_{4}(2)$ & 3.82 & $\mathrm{C}_{9}-\mathrm{C}_{11}(3)$ & 3.98 & $\mathrm{C}_{6}-\mathrm{O}_{3}(4)$ & 3.82 \\
$\mathrm{O}_{3}-\mathrm{O}_{4}(2)$ & 3.61 & $\mathrm{C}_{9}-\mathrm{C}_{11}^{\prime}(3)$ & 3.80 & $\mathrm{C}_{7}-\mathrm{O}_{3}(4)$ & 3.74 \\
$\mathrm{O}_{1}-\mathrm{O}_{2}(3)$ & 3.62 & $\mathrm{C}_{10}-\mathrm{C}_{11}^{\prime}(3)$ & 3.98 & & \\
\hline
\end{tabular}

a Distance between atoms of molecules at $x, y, z$ and at (2) $x+1, y, z$, (3) $x, y+1, z$, or (4) $x+1, y+1, z$.

b Hydrogen-bonded distance.

c Atom related by the center of symmetry at $(0,0,1 / 2)$ with that of the same number.

The hydrogen bonds between the adjacent molecules are formed in a sheet and the neighbouring sheets are bound by van der Waals attraction forces. ${ }^{1,14}$ The members with $m=$ odd and $n=$ even have distorted conformations in which the hydrogen-bonded sheets are formed parallel to the $b c$-plane. ${ }^{1,14}$ Those with $m=$ even and $n=$ odd form two-dimensional networks of hydrogen bonds parpendicular to the molecular axes. The networks of hydrogen bonds in the latter two groups are very different from each other, and consist of the molecules so distorted from the planar zig-zag conformation as to satisfy the condition of full hydrogen bonding. The members with $m=$ even and $n=$ odd are particularly more crystalline than the other members, probably due to two-dimensional networks of hydrogen bonds. These polymers can hardly be doubly oriented by extension with a roller, while the other members can easily be oriented in two directions, since the hydrogen-bonded sheets are parallel to the rolled planes. Polyurethanes with $m, n=$ odd are hardly crystallizable and consequently their crystal structures have not as yet been investigated.

\section{REFERENCES}

1. Y. Saito, S. Nansai, and S. Kinoshita, Polym. J., 3, 1139 (1972).

2. J. J. Beres and L. Alexander, Acta Crystallogr., Sect. $B$, 32, 2077 (1976).

3. C. S. Marvel and J. H. Johnson, J. Am. Chem. Soc., 72, 1974 (1950).

4. Y. Iwakura and K. Nagakubo, Yuki Kagobutsu Goseiho, 10, 104 (1958). 
5. T. Tanaka, T. Yokoyama, and Y. Yamaguchi, $J$. Polym. Sci., A-1, 6, 2137 (1968).

6. W. MacKnight and M. Yang, J. Polym. Symp., 42, 817 (1973).

7. T. Ota, M. Yamashita, Y. Yoshizaki, and E. Nagai, J. Polym. Sci., A-2, 4, 959 (1968).

8. C. W. Bunn, J. Appl. Chem., 1, 266 (1951).

9. L. Pauling, R. B. Corey, and H. R. Branson, Proc. Natl. Acad. Sci. U.S.A., 37, 205 (1951).

10. H. Tadokoro, "Structure of Crystalline Polymers,"
Interscience, New York, N.Y., 1979, Chapter 4-6.

11. G. E. Schulz and R. E. Schirmer, "Principles of Protein Structure," Springer-Verlag, New York, N.Y., 1979, Chapter 2-6.

12. Y. Kinoshita, Makromol. Chem., 33, 1, 21 (1959).

13. L. Pauling, "The Nature of the Chemical Bond," 3rd ed, Cornell Univ. Press, Ithaca, N.Y., 1960, Chapter 12.

14. Y. Saito and S. Kinoshita, to be published. 